\title{
CHARACTERIZATION AND GENETIC VARIABILITY ANAL YSIS IN Capsicum annuum L. GERMPLASM
}

\author{
S. Datta ${ }^{1}$ and L. Das \\ Department of Vegetable and Spice Crops, Uttar Banga Krishi Viswavidyalaya \\ Cooch Behar - 736165,West Bengal, India,
}

\begin{abstract}
Fifty three genotypes of Capsicum annuum L. collected from different parts of the West Bengal, India were characterized for 23 characters namely, stem colour, plant growth habit, branching habit, leaf size, leaf shape, leaf margin, leaf colour, leaf pubescence, pigment at node, flower per axil, corolla colour, anther colour, calyx margin, mature fruit colour at intermediate stage, fruit shape, fruit position, fruit adherence to the calyx, fruit shape at pedicel attachment, blossom end fruit shape, ascorbic acid content of the fruit, capsaicin in red fruit and colour value of the ripe fruit. These genotypes upon cataloguing showed distinct variations with respect to vegetative, inflorescence, fruit and quality characters. A wide range of variation was also observed among the genotypes for several morphological, fruit and quality characters. Among the different characters, white corolla colour showed $100 \%$ frequency and higher frequency was also recorded in single flower per axil (86.79\%), number pigmentation at node (83.02 \%) and green fruit colour $(69.81 \%)$ at intermediate stage. Predominance of single descriptor state was found in more than $50 \%$ genotypes for 15 characters. Based on the $D^{2}$ value 53 genotypes were grouped into 17 clusters and results indicated that Cluster I and Cluster VII comprised with 29 and 9 genotypes respectively. Rest of clusters consisted of one genotype in each case. Variability studies revealed that there was a wide range of variability for all the characters studied. High heritability along with higher genetic advance (as a \%age of mean) was found in capsaicin content in fruit, number of fruits per plant, yield per plant and primary branches per plant. These characters may be considered as reliable selection indices as they are possibly governed by additive gene effect.
\end{abstract}

Key Words: Chilli, characterization, cluster, utilization, variability

\footnotetext{
${ }^{1}$ Corresponding author email: suchanddatta@rediffmail.com
}

Received: 17.02.2013 


\section{INTRODUCTION}

Chilli (Capsicum annuum L.) is one of the important commercially grown vegetable cum spice crops in the terai zone of West Bengal, India. Chilli is mainly used for its pungency and pleasant flavor. Consumption of small amount of chilli enriches diet and considered as of minerals, vitamins and other food components (Farhad et al., 2010). The genus Capsicum originated in the American tropics. Five species of capsicum were cultivated in different parts of the World (Pickergill, 1997). It is probably introduced by Portuguese into Southern parts of India and cultivation spread out throughout India by the end of $19^{\text {th }}$ century. Due to long history of cultivation, selection and popularity of crops sufficient genetic variability has been generated. Rich variability in morphological traits in hot pepper occurs through out India particularly in south peninsular region, North Eastern foot hills of Himalayas and Gangetic plains (Pradheep and Veeraragavathatham, 2006). Collection and maintenance of the genetic diversity in capsicum are important to avoid genetic erosion. Besides the identification of species, the characterization and evaluation of genotypes maintained in gene banks are of fundamental importance (Sudre et al., 2006). Genetic cataloguing based on standard descriptors helps to easily describe the morphological features of a genotype and thus helps exchange of information about new genotypes. Characterization and evaluation of germplasm are prerequisite for the utilization of the available diversity in the chilli improvement programme. Desirable parental combinations provide the basis for selection in the follow up hybrid breeding process for exploitation of heterosis (Thul et al., 2009). Desirable parental combination can be identified on the basis of cluster analysis. To initiate any breeding work, it is necessary to assess the genetic variability present in the indigenous genotypes for yield and its components. Parameter of genotypic and phenotypic coefficient of variations is useful in detecting the amount of variability present in the germplasm. Heritability and genetic advance helps in determining the influence of environment in expression of the characters and the extent to which improvement is possible after selection. Hence, the genotypes were characterized to assess the variability and identification of promising genotypes which can be used in further breeding programme.

\section{MATERIALS AND METHODS}

The present experiment was carried out at the experimental field of Uttar Banga Krishi Viswavidyalaya, Pundibari, Cooch Behar, West Bengal, India. Geographically the experimental field is situated at $26^{0} 19^{\prime} 86^{\prime \prime} \mathrm{N}$ latitude and $89^{\circ} 23^{\prime} 53^{\prime \prime}$ E longitude, at an elevation of 43 meter above mean sea level with an objective of characterization of collected germplasm of chilli. Fifty three genotypes (Table 1) were evaluated in Randomized Complete Block Design with three replications during the rabi (winter) season of 2006-07 and 2007-08. The climatic condition of terai zone is sub-tropical humid in nature characterized by high rainfall, high relative humidity, moderate temperature, prolonged winter with high residual soil moisture. The experimental soil 
was sandy clay loam having $\mathrm{p}^{\mathrm{H}}$ 5.6. The soil contains $0.91 \%$ organic carbon, 133.78 $\mathrm{kg} \mathrm{ha}^{-1}$ available nitrogen, $45.72 \mathrm{~kg} \mathrm{ha}^{-1}$ available phosphorus and $59.35 \mathrm{~kg} \mathrm{ha}^{-1}$ available potash. Healthy and uniform seedlings were transplanted in plots of $3.60 \mathrm{~m}$ x $3.0 \mathrm{~m}$ size with a spacing of $30 \mathrm{~cm}$ x $45 \mathrm{~cm}$ during middle of November. Organic manure@15 t ha-1 was applied as basal. Inorganic fertilizers were applied @100: 50: $50 \mathrm{~kg} \mathrm{ha}^{-1} \mathrm{~N}: \mathrm{P}_{2} \mathrm{O}_{5}: \mathrm{K}_{2} \mathrm{O}$. Full dose of $\mathrm{P}_{2} \mathrm{O}_{5}$, half dose of $\mathrm{K}_{2} \mathrm{O}$ and one third of nitrogen was given as basal dose at the time of land preparation. After 45 days of transplanting top dressing was done with one third of nitrogen and rest half $\mathrm{K}_{2} \mathrm{O}$. Second top dressing was done with rest one third of nitrogen at 75 days after transplanting. Observation on different morphological and yield attributing characters were recorded from ten randomly selected plants from each replications. Plant height was measured by meter scale from the base of the plant to the tip of the top leaf at full bearing stage. Number of primary branches per plant were counted at the time of full bearing stage. Harvesting of chilli was done at the mature green stage when a few number of fruits change colour from green to red considering consumer preference. Harvesting of the mature fruit was done at 15 days interval. The fruit yield of chilli per plant was recorded as average of cumulative yield of all pickings at mature green fruit stage of 10 plants and measured in gram. Total quantity of chilli harvested in each picking was added to get plot yield. Yield per hectare was calculated on the basis of plot yield considering $80 \%$ area occupied by the crop in these experiments and measured in the unit of tones per hectare. Chlorophyll content of leaf was measured by Chlorophyll Meter Minolta Sensing, INC, Japan) with the unit of SPAD-502 at the time of first harvest. Ascorbic acid in chilli fruit was determined by colorimetric method based on the reduction of 2, 6- dichlorophenol indophenol by ascorbic acid and was expressed in milligram of ascorbic acid per $100 \mathrm{~g}$ of sample (Ranganna, 2001). Capsaicin content (\%) of green fruits was measured by Spectrophotometer Method as described by Sadasivam and Manickam (1996). Colour value (in ASTA Unit) of red fruits was measured by using American Spice Trade Association techniques as suggested by Pruthi (1999). Characterization for most of the characters was done on ten randomly selected plants from each genotype as per the descriptor list of IBPGR for capsicum (IBPGR, 1995). Mahanalobis D ${ }^{2}$ statistics was used for assessing the genetic divergence among the genotypes. The grouping of the population was done by using Tocher's method as described by Rao (1952). The genotypic and phenotypic coefficient of variation (GCV and PCV respectively) was calculated on the basis of formula given by Burton (1952). Heritability in broad sense was calculated according to the formula suggested by Jhonson et al. (1955). Genetic advance were calculated according to the method worked out by Allard (1960).

\section{RESULTS AND DISCUSSION}

\section{Characterization}

A wide range of variation was observed among the genotypes for several morphological characters (Table 2A and Table 2B). The genotypes were characterized by green to purple stem colour and majority of the genotypes showed 
green and green with purple stripe stem colour. Plant growth habit varied from prostrate to erect and intermediate growth habit was dominant (58.49\%) followed by prostrate (35.85 \%). Majority of the genotypes showed dense branching habit (50.94 $\%)$ followed by intermediate (41.51\%). Most of the genotypes had sparse leaf pubescence (67.92 per ent) with green (62.26 \%) and dark green $(33.96 \%)$ in colour and leaf shape was lanceolate (58.49 \%) and ovate (39.62 \%) with entire (52.83\%) and undulate (47.17 \%) leaf margin. Manju and Sreelathakumary (2002) reported that in $90 \%$ cases leaf colour was green and $87.55 \%$ had sparse leaf pubescence in case of Capsicum chinense germplam. In the present experiment, more than $50 \%$ cases leaf colour was green and having sparse leaf pubescence. Here the slight variation might be due to variation in Capsicum species and germplasm. Based on leaf size, the genotypes could be grouped into three distinct classes namely small (49.06\%), medium (39.62 \%) and large (11.32\%). Pigmentation in node was present in most of the genotypes (83.02\%). Flowers per axil were one (86.79\%), two $(7.55 \%)$ and three or more (5.66\%). All the genotypes had white colour corrolla with pale blue (37.74 \%), purple (13.21\%), blue (5.66 \%) or other colour (43.40\%) anther. Calyx margin was intermediate (49.06 \%), dentotate (43.40\%) and entire (7.55 \%). Mature fruit colour at intermediate state was green $(69.81 \%)$ followed by others $(26.42 \%)$ and purple $(3.77 \%)$. Similar findings with respect to mature fruit colour were also reported by Pradheep andVeeraragavathatham (2006). Based on fruit shape, the genotypes could be grouped into five distinct morphological classes namely elongate (9.43\%), triangular (41.51\%), campanulate (22.64\%), all most round (24.53\%\%) and others $(1.89 \% \%)$. Most of the genotypes produced fruit under pendent (69.81 $\%)$, erect (26.42 \%) and semi pendent position (3.77\%). Hard adherence of fruit to calyx (52.83 per cent) was the dominant one followed by semi hard adherence (32.08 per cent) and loose (15.10 per cent). At pedicel attachment, fruit shape was acute (33.96 per cent), obtuse $(22.64 \%)$ truncate $(28.31 \%)$ or lobate $(15.09 \%)$. Based on blossom end fruit shape, the genotypes could be classified into five distinct morphological classes namely, pointed (45.28 \%), blunt (32.08\%), shrunken (7.55\%), shrunken and pointed (7.55 \%) and blunt (7.55\%). Surface of the mature fruit was smooth $(37.74 \%)$, Semi wrinkled (49.05 \%) or wrinkled (13.21 \%). High variability for morphological characters in $C$. annumm was also reported by Sreelathakumary (2000), which was similar with the present experiment.

\section{Genetic diversity of the genotypes}

The data on clustering pattern have been presented in figure1. Analysis of variance revealed that the genotypes varied significantly for all the characters under study. Based on the $\mathrm{D}^{2}$ value 53 genotypes were grouped into 17 clusters and such results indicated that Cluster I and Cluster VII comprised with 29 and 9 genotypes respectively. Rest of clusters consisted of one genotype in each case. The clustering pattern revealed that there was no association of species and geographical distribution for the formation of cluster in genetic divergence. Similar findings were also reported by Sreelathakumary and Rajmony (2004), Indra et al. (2000), and (Farhad et al., 2010). 


\section{Intra and Inter cluster divergence}

The data on intra and inter cluster distance have been presented in table 3 . Among the different clusters maximum intra cluster distance (5.90) was recorded in cluster VII. Maximum inter Cluster distance (12.89) was observed in between Cluster XVII (CA-28) and Cluster XVI (CA-20), followed by 12.13 in Cluster XVII (CA28) and Cluster V (CA-14) and 11.89 in Cluster XVII (CA-28) and Cluster IX (CA42). So, the genotypes included in these clusters have the greater divergence and hence the crossings between the genotypes in these clusters were expected to give desirable recombinants.

\section{Genetic variability}

The data on range, mean and genotypic coefficient of variation (GCV), phenotypic coefficient of variation (PCV), heritability in broad sense $\left(\mathrm{H}^{2}\right)$, genetic advance (GA), genetic advance as \% mean (GAM) of the different characters have been presented in table 4 . It is evident from the above table there was a wide range of variability for all the characters providing an ample scope for selecting desirable types. Maximum range was observed in fruit number (52.30-168.23) followed by plant height (34.20-105.20 cm), ascorbic acid (75.89-167.21 mg per $100 \mathrm{~g}$ fresh), etc.

Close estimates of GCV and PCV were recorded for most of the characters indicated that contribution towards final phenotypic expression of these characters was mostly by genetic architecture of the genotypes rather than environmental factors. Similar findings were also recorded by Choudhury and Samadia (2004). It was evident that the higher magnitude of GCV was observed in number of fruits per plant $(25.62 \%)$, followed by yield per ha $(22.34 \%)$, etc. Except plant spread and ascorbic acid content in green fruit, the rest characters showed more than $80 \%$ heritability. High estimates of heritability of the above characters have been found useful for selection on the basis of phenotypic performance. Higher estimates of heritability of the above characters might be due to additive gene effect (Narayana et al., 1996). So, these characters could be considered as reliable selection indices and selection on the basis of these characters might be rewarding. Findings with respect to primary branches per plant, fruit length, fruit yield per plant were supported by Nandadevi and Housamani (2003). In case of plant height findings of the present experiment was in close conformity with the findings of Choudhury and Samadia (2004). Very high heritability along with high genetic advance offers effective criteria for selection. But for better comparison of GA was converted to GA as \% of mean. High heritability estimates coupled with high expected GA as \% of mean were observed in case of number of fruits per plant, capsaicin content on red fruit and yield per ha. Findings of the present experiment were in conformity with Ukkund et al., (2007). Higher estimates of heritability of the above characters might be due to additive gene effect. So, these characters could be considered as reliable selection indices and selection on the basis of these characters might be rewarding. 
From the above discussion it may be concluded that there was a wide variability among the different germplasm for most of the characters studied. So, these germplasm may be utilized for future breeding programme. On the basis of higher estimates of inter cluster distance of 12.89 as observed between Clusters XVII (CA-28) and Cluster XVI (CA-20), followed by 12.13 between Clusters XVII (CA-28) and Cluster V (CA-14) and 11.89 between Clusters XVII (CA-28) and Cluster IX (CA-42), desirable parents might be chosen from the above clusters for effective crossing programme. Moreover, selection on the germplasm may be effective and rewarding with respect to those characters having high heritability along with higher genetic advance as a \% of mean like high in capsaicin content in fruit, number of fruits per plant, yield per plant and primary branches per plant as these parameters are governed by additive gene effect.

Table 1: List of different chilli genotypes along with sources of collection

\begin{tabular}{|c|l|l|l|l|l|}
\hline SN & $\begin{array}{c}\text { Variety/ } \\
\text { cultivar }\end{array}$ & \multicolumn{1}{|c|}{ Collection area/Source } & Sl no & $\begin{array}{l}\text { Variety/ } \\
\text { cultivar }\end{array}$ & \multicolumn{1}{|c|}{ Collection area/Source } \\
\hline 1 & CA - 1 & $\begin{array}{l}\text { Raijanj, Uttar Dinajpur, West } \\
\text { Bengal (W.B.). }\end{array}$ & 28 & CA - 28 & Delhi \\
\hline 2 & CA -2 & Tufanjanj, Cooch Behar, W.B.. & 29 & CA - 29 & Sajerpar, Cooch Behar, W.B. \\
\hline 3 & CA -3 & Tufanjang, Coochbehar, W.B. & 30 & CA - 30 & Dinhata, Cooch Behar, W.B. \\
\hline 4 & CA- 4 & Sealdah market, Kolkata, W.B. & 31 & CA - 31 & Madhupur, Cooch Behar, W.B \\
\hline 5 & CA- 5 & Suri, Birbhum, W.B. & 32 & CA - 32 & Madhupur, Cooch Behar, W.B \\
\hline 6 & CA -6 & Malda, W.B. & 33 & CA - 33 & Madhupur, Cooch Behar, W.B \\
\hline 7 & CA -7 & Haldi bari, Cooch Behar, W.B. & 34 & CA - 34 & Madhupur, Cooch Behar, W.B \\
\hline 8 & CA -8 & $\begin{array}{l}\text { Balurghat, Dahshin Dinajpur, } \\
\text { W.B. }\end{array}$ & 35 & CA - 35 & Madhupur, Cooch Behar, W.B \\
\hline 9 & CA -9 & Jalpaiguri, W.B. & 36 & CA - 36 & Madhupur, Cooch Behar, W.B \\
\hline 10 & CA -10 & Jalpaiguri, W.B. & 37 & CA - 37 & Madhupur, Cooch Behar, W.B \\
\hline 11 & CA -11 & Haldibari, Cooch Behar, W.B. & 38 & CA - 38 & Madhupur, Cooch Behar, W.B \\
\hline 12 & CA -12 & Haldibari, Cooch Behar, W.B. & 39 & CA - 39 & Bhubaneswar, Orissa \\
\hline 13 & CA -13 & Ghugumari, Cooch Behar, W.B. & 40 & CA - 40 & Madhupur, Cooch Behar, W.B \\
\hline 14 & CA -14 & Pundibari, Cooch Behar, W.B. & 41 & CA - 41 & Cooch Behar market \\
\hline 15 & CA -15 & Pundibari, Cooch Behar, W.B. & 42 & CA - 42 & Cooch Behar market \\
\hline 16 & CA -16 & Balurghat, Dahshin dinajpur, W.B. & 43 & CA - 43 & Chilapata, \\
\hline 17 & CA -17 & Raiganj, Uttar dinajpur, W.B & 44 & CA - 44 & Chilapata, \\
\hline 18 & CA -18 & $\begin{array}{l}\text { Balurghat, Dahshin Dinajpur, } \\
\text { W.B. }\end{array}$ & 45 & CA - 45 & $\begin{array}{l}\text { Rajabhat Khawa, } \\
\text { jalpaiguri,W.B. }\end{array}$ \\
\hline 19 & CA -19 & $\begin{array}{l}\text { Balurghat, Dahshin Dinajpur, } \\
\text { W.B. }\end{array}$ & 46 & CA - 46 & Madhupur, Cooch Behar, W.B \\
\hline
\end{tabular}




\begin{tabular}{|c|l|l|l|l|l|}
\hline SN & $\begin{array}{c}\text { Variety/ } \\
\text { cultivar }\end{array}$ & \multicolumn{1}{|c|}{ Collection area/Source } & Sl no & $\begin{array}{c}\text { Variety/ } \\
\text { cultivar }\end{array}$ & Collection area/Source \\
\hline 20 & CA -20 & Murshidabad, W.B. & 47 & CA -47 & Madhupur, Cooch Behar, W.B \\
\hline 21 & CA -21 & Murshidabad, W.B. & 48 & CA - 48 & Madhupur, Cooch Behar, W.B \\
\hline 22 & CA -22 & Burdwan, W.B. & 49 & CA - 49 & Tufanjanj, Cooch Behar, W.B. \\
\hline 23 & CA -23 & Katwa, Burdwan, W.B. & 50 & CA - 50 & Chilapata, \\
\hline 24 & CA -24 & Bolpur, Birbhum, W.B. & 51 & CA - 51 & Tufanjanj, Cooch Behar, W.B \\
\hline 25 & CA -25 & Beldanga, Murshidabad, W.B. & 52 & CA - 52 & Tufanjanj, Cooch Behar, W.B \\
\hline 26 & CA -26 & Delhi & 53 & CA - 53 & Varanasi, UP. \\
\hline 27 & CA -27 & Delhi & & & \\
\hline
\end{tabular}

Table 2 A: Characterization of chilli germplam following descriptor based qualitative characters

\begin{tabular}{|c|c|c|c|c|}
\hline Character & Type & $\begin{array}{l}\text { Descriptor } \\
\text { code }\end{array}$ & $\begin{array}{l}\text { Number of } \\
\text { Genotypes }\end{array}$ & $\begin{array}{c}\text { Frequency } \\
(\%)\end{array}$ \\
\hline \multirow[t]{3}{*}{ Stem colour } & Green & 1 & 32 & 60.38 \\
\hline & $\begin{array}{l}\text { Green with } \\
\text { purple stripe }\end{array}$ & 2 & 20 & 37.74 \\
\hline & Purple & 3 & 1 & 1.89 \\
\hline \multirow[t]{3}{*}{ Plant growth habit } & Prostrate & 3 & 19 & 35.85 \\
\hline & Intermediate & 5 & 31 & 58.49 \\
\hline & Erect & 7 & 3 & 5.66 \\
\hline \multirow[t]{3}{*}{ Branching habit } & Sparse & 3 & 4 & 7.55 \\
\hline & Intermediate & 5 & 22 & 41.51 \\
\hline & Dense & 7 & 27 & 50.94 \\
\hline \multirow[t]{3}{*}{ Leaf size } & Small & - & 26 & 49.06 \\
\hline & Medium & - & 21 & 39.62 \\
\hline & Large & - & 6 & 11.32 \\
\hline \multirow[t]{3}{*}{ Leaf shape } & Ovate & 2 & 21 & 39.62 \\
\hline & Deltoid & 1 & 1 & 1.89 \\
\hline & Lanceolate & 3 & 31 & 58.49 \\
\hline \multirow[t]{2}{*}{ Leaf margin } & Entire & 1 & 28 & 52.83 \\
\hline & Undulate & 2 & 25 & 47.17 \\
\hline \multirow[t]{2}{*}{ Leaf colour } & Green & 3 & 33 & 62.26 \\
\hline & Other & 8 & 1 & 1.89 \\
\hline
\end{tabular}




\begin{tabular}{|l|l|c|c|c|}
\hline \multicolumn{1}{|c|}{ Character } & \multicolumn{1}{|c|}{ Type } & $\begin{array}{c}\text { Descriptor } \\
\text { code }\end{array}$ & $\begin{array}{c}\text { Number of } \\
\text { Genotypes }\end{array}$ & $\begin{array}{c}\text { Frequency } \\
\text { (\%) }\end{array}$ \\
\hline & Dark green & 4 & 18 & 33.96 \\
\hline & Purple & 6 & 1 & 1.89 \\
\hline Leaf pubescence & Sparse & 3 & 36 & 67.92 \\
\hline & Intermediate & 5 & 14 & 26.42 \\
\hline & Dense & 7 & 3 & 5.66 \\
\hline Pigment at node & Absent & - & 44 & 83.02 \\
\hline & Present & - & 9 & 16.99 \\
\hline Flower per axil & One & 1 & 46 & 86.79 \\
\hline & two & 2 & 4 & 7.55 \\
\hline & Three or more & 3 & 3 & 5.66 \\
\hline Corolla colour & White & 1 & 53 & 100 \\
\hline Anther colour & Pale blue & 3 & 20 & 37.74 \\
\hline & Blue & 4 & 3 & 5.66 \\
\hline & Other & 6 & 23 & 43.40 \\
\hline & Purple & 5 & 7 & 13.21 \\
\hline
\end{tabular}

Table 2 B: Characterization of chilli germplam following descriptor based on reproductive characters

\begin{tabular}{|l|l|c|c|c|}
\hline \multicolumn{1}{|c|}{ Character } & \multicolumn{1}{|c|}{ Type } & $\begin{array}{c}\text { Descriptor } \\
\text { code }\end{array}$ & $\begin{array}{c}\text { Number of } \\
\text { accession }\end{array}$ & $\begin{array}{c}\text { Frequency } \\
\text { (\%) }\end{array}$ \\
\hline Calyx margin & Entire & 1 & 4 & 7.55 \\
\hline & Intermediate & 2 & 26 & 49.06 \\
\hline & Dentoate & 3 & 23 & 43.40 \\
\hline $\begin{array}{l}\text { Mature fruit colour at } \\
\text { intermediate state }\end{array}$ & Green & 3 & 37 & 69.81 \\
\hline & Purple & 5 & 2 & 3.77 \\
\hline & Others & 7 & 14 & 26.42 \\
\hline Fruit shape & Elongate & 1 & 5 & 9.43 \\
\hline & Triangular & 4 & 22 & 41.51 \\
\hline & Campunulate & 5 & 12 & 22.64 \\
\hline & Almost round & 2 & 13 & 24.53 \\
\hline & Others & 6 & 1 & 1.89 \\
\hline Fruit position & Pendent & - & 37 & 69.81 \\
\hline
\end{tabular}




\begin{tabular}{|c|c|c|c|c|}
\hline Character & Type & $\begin{array}{l}\text { Descriptor } \\
\text { code }\end{array}$ & $\begin{array}{l}\text { Number of } \\
\text { accession }\end{array}$ & $\begin{array}{c}\text { Frequency } \\
(\%)\end{array}$ \\
\hline & Semi pendent & - & 2 & 3.77 \\
\hline & Erect & - & 14 & 26.42 \\
\hline \multirow[t]{3}{*}{ Adherence to calyx } & Loose & - & 8 & 15.10 \\
\hline & Semi hard & - & 17 & 32.08 \\
\hline & Hard & - & 28 & 52.83 \\
\hline \multirow{4}{*}{$\begin{array}{l}\text { Fruit shape at pedicel } \\
\text { attachment }\end{array}$} & Acute & 1 & 18 & 33.96 \\
\hline & Obtuse & 2 & 12 & 22.64 \\
\hline & Truncate & 3 & 15 & 28.31 \\
\hline & Lobate & 5 & 8 & 15.09 \\
\hline \multirow[t]{5}{*}{$\begin{array}{l}\text { Blossom end fruit } \\
\text { shape }\end{array}$} & Pointed & 1 & 24 & 45.28 \\
\hline & Blunt & 2 & 17 & 32.08 \\
\hline & $\begin{array}{l}\text { Shurken and } \\
\text { pointed }\end{array}$ & 4 & 4 & 7.55 \\
\hline & Semi blunt & 5 & 4 & 7.55 \\
\hline & Shurken & 3 & 4 & 7.55 \\
\hline \multirow[t]{3}{*}{ Fruit surface } & Smooth & 1 & 20 & 37.74 \\
\hline & Semi wrinkled & 2 & 26 & 49.05 \\
\hline & Wrinkled & 3 & 7 & 13.21 \\
\hline \multirow[t]{3}{*}{$\begin{array}{l}\text { Ascorbic acid (mg/100 } \\
\text { g fresh) }\end{array}$} & Bellow 100 & - & 3 & 5.66 \\
\hline & $100-150$ & - & 44 & 83.02 \\
\hline & Above 150 & - & 6 & 11.32 \\
\hline \multirow[t]{3}{*}{$\begin{array}{l}\text { Capsaicin in red fruit } \\
\text { (\%) }\end{array}$} & Below 0.5 & - & 18 & 33.96 \\
\hline & $0.50-1.00$ & - & 31 & 58.49 \\
\hline & Above 1.00 & - & 4 & 7.55 \\
\hline \multirow[t]{4}{*}{ Colour value } & Bellow 50 & - & 2 & 3.77 \\
\hline & $50-100$ & - & 21 & 39.62 \\
\hline & $101-150$ & - & 22 & 41.51 \\
\hline & Above 150 & - & 8 & 15.09 \\
\hline
\end{tabular}




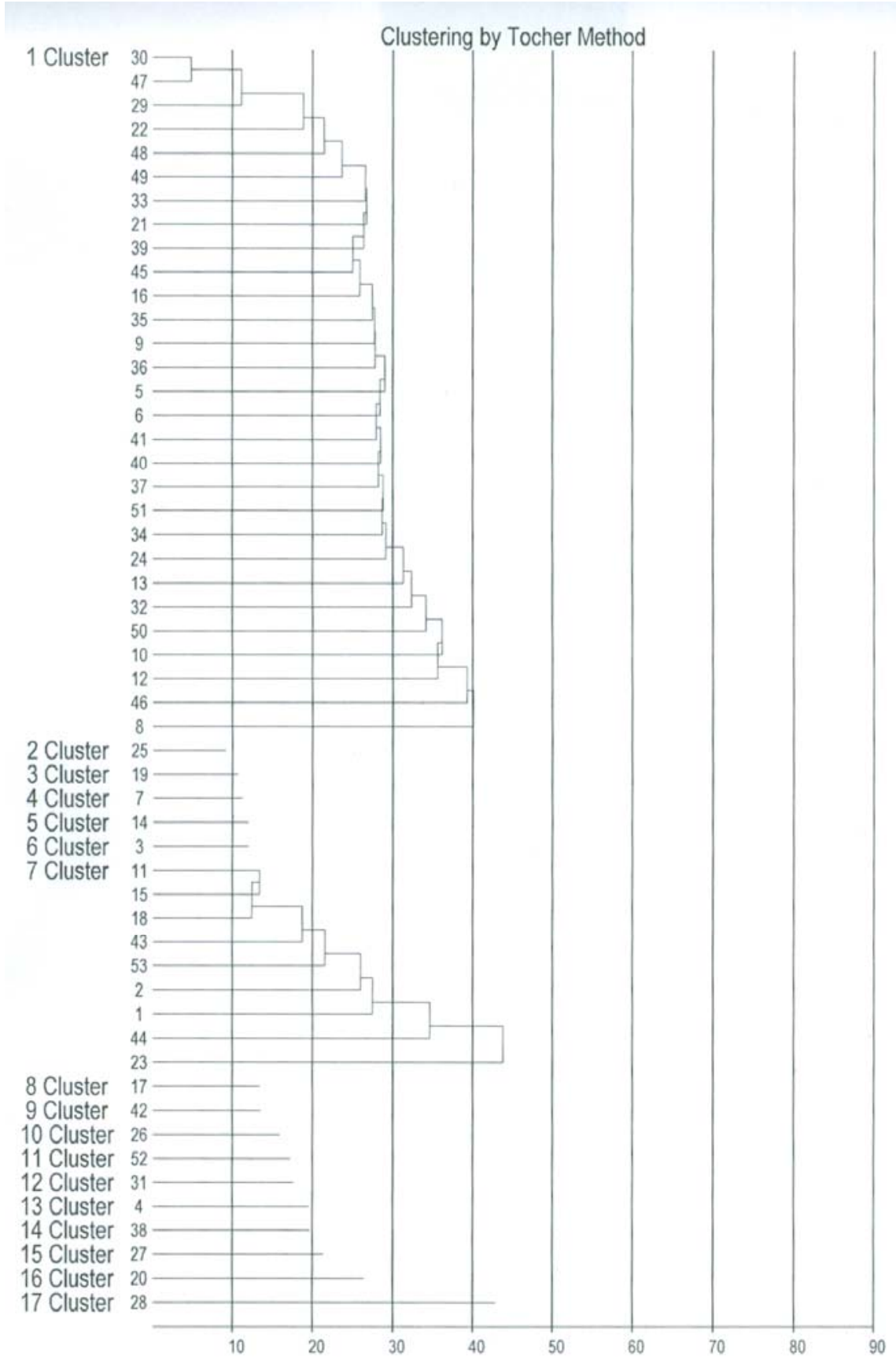

Figure 1: Cluster wise distribution of fifty three chilii genotypes 
Table 3: Average inter and intra cluster distances of 17 clusters of chilli germplaasm

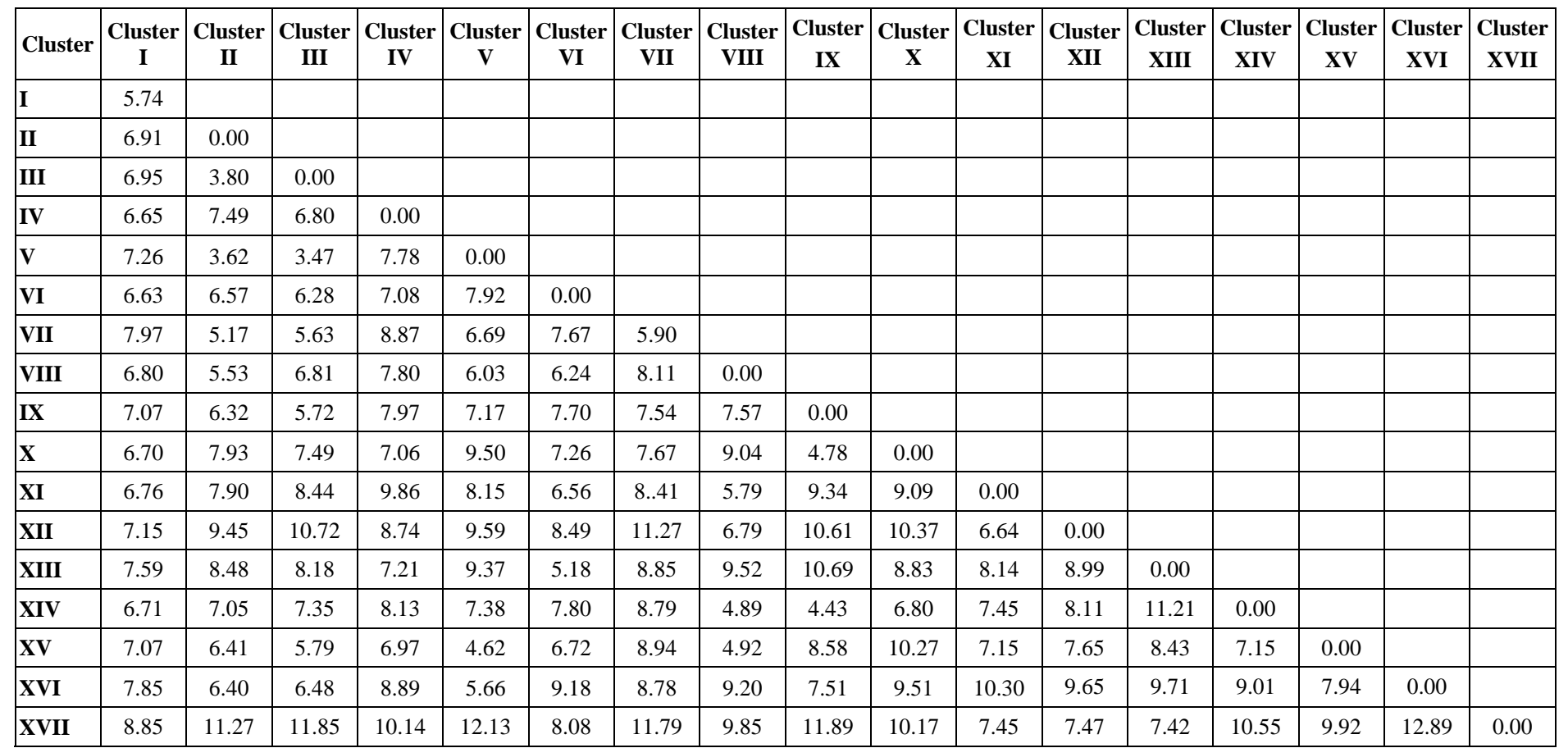


Table 4: Range, mean and genotypic and phenotypic coefficient of variation, heritability and genetic advance of the different characters of chilli

\begin{tabular}{|l|c|c|c|c|c|c|c|}
\hline & Range & Mean & GCV & PCV & Heritability & GA & $\begin{array}{l}\text { GA as } \\
\text { mean }\end{array}$ \\
\hline Plant height (cm) & $34.20-105.20$ & 80.08 & 15.44 & 16.44 & 86.10 & 23.64 & 37.81 \\
\hline $\begin{array}{l}\text { Primary branches per } \\
\text { plant }\end{array}$ & $4.33-8.50$ & 6.21 & 11.98 & 12.47 & 92.30 & 1.45 & 30.39 \\
\hline Plant spread (cm) & $37.43-56.60$ & 51.33 & 7.24 & 8.17 & 78.50 & 6.79 & 16.94 \\
\hline Fruit numbers per plant & $54.30-168.23$ & 112.70 & 25.62 & 26.56 & 93.00 & 57.35 & 66.21 \\
\hline $\begin{array}{l}\text { Leaf chlorophyll } \\
\text { content (SPAD-502) }\end{array}$ & $50.87-66.74$ & 59.10 & 4.98 & 5.46 & 83.20 & 5.53 & 11.98 \\
\hline $\begin{array}{l}\text { Ascorbic acid (mg/100 } \\
\text { g fresh fruit) }\end{array}$ & $75.89-167.21$ & 122.25 & 6.32 & 8.47 & 55.60 & 11.86 & 12.44 \\
\hline Yield per plant (g) & $61.38-196.29$ & 147.38 & 22.34 & 23.42 & 91.00 & 4.37 & 56.29 \\
\hline $\begin{array}{l}\text { Capsaicin content in } \\
\text { red fruit (\%) }\end{array}$ & $0.33-1.13$ & 0.67 & 45.17 & 45.29 & 99.48 & 0.64 & 95.52 \\
\hline
\end{tabular}

\section{REFERENCES}

Allard, R. W. 1960. Principles of plant Breeding. Jhon Wiley and Sons Inc., New York

Burton, G. W.1952. Quantitative inheritance in grasses. Pioceeding of $6^{\text {th }}$ International Grassland Congress, 1, 227-283.

Choudhary, B. S. \& Samadia, D. K. 2004. Variability and character association in chilli landraces and genotypes under arid environment. Indian Journal of Horticulture, 61 (2), 132-136.

Indra, P., Peter, K. V. \& Unnithan, V. K. G. 2000. Divergence in chilli. Spice India 13 (4): 15-20.

International Plant Genetic Resources Institute (IPGRI).1995. Descriptores para Capsicum (Capsicum spp.). International Plant Genetic Resources Institute (IPGRI), Rome.

Farhad, M., Hasanuzzaman, M., Biswas, B. K., Ariifuzzaman, M. \& Islam, M. M. 2010. Genetic divergence in chilli (Capsicum annuum L.). Bangladesh Research Publications Journals, 3(3):1045-1051

Jhonson, H. W., Rbinson, H. F. \& Comstock, R. F. 1955. Estimate of genetic and environmental variability. Agronomy Journal, 47: 314-318.

Nandadevi, \& Hosamani, R. M. 2003. Variability, correlation and path analysis in kharifgrown chilli (Capsicum annuum L.) genotypes for different characters. Capsicum and Eggplant Newsletter, 22: 43-46.

Narayana, R., Singh, S. P., Sharma, D. K. \& Rastogi, K. B. 1996. Genetic variability and selection parameters in bottle gourd. Indian Journal of genetics and Plant Breeding, 17: 312-318. 
Manju, P. \& Sreelathakumary, I.2002. Genetic cataloguing of hot chilli (Capsicim cinense JACQ) types of Kerala. Journal of Tropical Agriculture, 40: 42-44

Pickersgill, B. 1997. Genetic resources and breeding of Capsicum spp. Euphytica, 96, 129133

Pradheep, K. \& Veeraragavathatham, D. 2006. Characterization of Capsicum spp. germplasm. Indian Journal of Plant Genetic Resources, 19(2):180-183

Pruthi, J. S. 1999. Quality Assurance in Spices and Spice Products, (pp 175-176), Allied Publishers, New Delhi.

Ranganna, S. 2001. Analysis and quality control for fruits and vegetable products. Tata Mc Grawhill Publication. $2^{\text {nd }}$ Edition (pp. 110-112), New Delhi, India.

Sadasivam, S. \& Manickam, A. 1996. Ascorbic Acid. In: Biochemical methods.New Age International Publishers (pp. 185-186), ( $2^{\text {nd }}$ Edition), New Delhi, India.

Sreelathakumary, I. 2000. Genetic analysis of shade tolerance in chilli (Capsicum spp.). Ph.D. Thesis. Kerala Agricultural University, Thrissur, p. 153

Sudre, C. P., Gonçalves, L. S. A., Rodrigues, R., Amaral Júnior do A. T., Riva Souza, E. M. \& Bento, C. dos S. 2010. Genetic variability in domesticated Capsicum spp as assessed by morphological and agronomic data in mixed statistical analysis. Genetics and Molecular Research, 9(1):283-294

Rao, C. R. 1952. Advance Statistical Method for Biometrical Research,( p 390), John Wiley and sons, New York.

Sreelathakumary, I. \& Rajmony, L. 2004. Genetic divergence in chilli (Capsicum annuum L.). Indian Journal of Horticulture, 61(2):137-139.

Thul, S. T., Lal, R. K., Shasany, A. K., Darokar, M. P., Gupta, A. K., Gupta, M. M., Verma, R. K. \& Khanuja, S. P. S. 2009. Estimation of phenotypic divergence in a collection of Capsicum species for yield related traits. Euphytica,

Ukkund, K. C., Madalageri, M. B., Patil, M. P., Mulage, R. \& Kotikal, K. 2007. Variabilty studies in green chill (Capsicum annuum L). Karnataka Journal of Agricultural Sciences, 20(1): 102-104. 